\title{
IDENTIFIKASI KUALITAS BIJI JAGUNG MANIS LAYAK JUAL DARI WARNA DAN TEKSTUR MENGGUNAKAN HSV DAN GRAY LEVEL RUN LENGTH MATRIX (GLRLM)
}

\author{
Mungki Astiningrum. ${ }^{1}$, Arie Rachmad Syulistyo. ${ }^{2}$,M. Alfin Zakariya. ${ }^{3}$ \\ 1,2,3 Teknologi Informasi, Teknik Informatika, Politeknik Negeri Malang \\ 1'mungki.astiningrum@polinema.ac.id, ${ }^{2}$ arie.rachmad.s@polinema.ac.id, ${ }^{3}$ alfinzakariya@gmail.com,
}

\begin{abstract}
Abstrak
Jagung manis adalah salah satu jenis sayuran yang sering dikonsumsi oleh masyarakat. Jagung manis memiliki kandungan gizi yang tinggi sehingga baik untuk dijadikan makanan alternatif selain nasi dan banyak dijadikan makanan olahan kuliner yang belakangan ini ramai di kalangan masyarakat. Karena itu kebutuhan masyarakat terhadap jagung manis yang semakin tinggi memerlukan adanya evaluasi kualitas jagung manis yang layak jual. Pada kenyataannya industri di Indonesia dalam mengevaluasi biji jagung manis masih menggunakan cara manual dengan mengandalkan indra manusia yang dimana hasil keluaran evaluasi tersebut tidak konsisten. Penelitian ini membahas mengenai evaluasi biji jagung manis dengan menggunakan Warna HSV (Hue, Saturation, Value) dan Tekstur Gray Level Run Length Matrix (GLRLM) dengan sistem pengolahan citra digital dengan cara mengolah nilai pada citra biji jagung manis kemudian diklasifikasikan menggunakan metode K-NN (K-Nearest Neighbor). Berdasarkan hasil dari penelitian ini diketahui bahwa penggunaan warna HSV dan metode tekstur GLRLM dengan fitur SRE (Short Run Emphasis), LRE (Long Run Emphasis), RLU (Run Length Uniformity) dan GLU (Gray Level Uniformity) dapat mengidentifikasi kualitas biji jagung manis. Dataset yang digunakan berjumlah 160 biji jagung manis di mana terdapat 4 kelas biji jagung manis, setiap input citra terdapat 10 biji jagung manis. Untuk data training total 30 biji segar, 30 biji patah segar, 30 basi, dan 30 patah basi. Untuk data testing terdapat 40 biji jagung manis dan masing citra terdapat 10 biji jagung manis dengan kelas yang berbeda. Tingkat akurasi tertinggi pada sistem untuk mengidentifikasi kualitas biji jagung manis layak jual sebesar $85 \%$ diperoleh pada derajat tekstur 45, 90, dan 135 dari nilai $\mathrm{K}=1, \mathrm{~K}=3$, dan $\mathrm{K}=9$. Dari data tersebut disimpulkan bahwa sistem dapat mengidentifikasi kualitas biji jagung manis dengan baik.
\end{abstract}

Kata kunci : Pengolahan Citra Digital, Jagung Manis, Gray Level Run Length Matrix, HSV, K-NN.

\section{Pendahuluan}

Kemajuan dan pemanfaatan IPTEK berkembang secara cepat. Dengan adanya teknologi aktivitas manusia akan menjadi lebih efektif. Teknologi bisa diterapkan hampir semua bidang seperti pertanian, kesehatan, pemerintah, ekonomi dan sebagainya.

Pengolahan citra digital adalah salah satu teknologi image processing yang memanfaatkan citra suatu gambar untuk keperluan tertentu contohnya seperti di bidang pertanian mengidentifikasikan kematangan suatu buah, kualitas sayur dan sebagainya. Di Indonesia, sebagian besar masyarakat mengandalkan di sektor pertanian. Jagung manis adalah salah satu tanaman yang banyak di produksi dan sumber bahan pokok pangan di Indonesia seperti dibuat olahan makanan, minuman, dan sebagainya. Untuk masalah kualitas biji jagung manis yang ada di pasaran ada beberapa yang memiliki kualitas yang meragukan seperti tidak segar. Penanganan yang kurang baik terhadap biji jagung manis akan berakibat turunnya kualitas nilai jual terhadap biji jagung tersebut sehingga berdampak tidak layak jual di pasar.
Biji jagung manis memiliki rasa manis daripada biji jagung biasa. Untuk warna dari biji jagung manis memiliki warna kuning berbeda dengan jagung biasa yang memiliki warna orange cerah, jagung biasa sering digunakan untuk pakan ternak. Jagung manis dikonsumsi pada usia muda, untuk jagung biasa di panen pada usia tua dan mengering.

\section{Tinjauan Pustaka}

\subsection{Penelitian Terdahulu}

Jurnal hasil penelitian dari Ulla Delfana Rosiani, Mustika Mentari, Andi Novan Prastya yang berjudul "Klasifikasi Kualitas Biji Jagung Berdasarkan Deteksi Warna dan Bentuk Menggunakan Metode K-Nearest Neighbor". Dari jurnal tersebut peneliti menggunakan sample biji jagung yang terdiri atas biji utuh, biji rusak, dan biji berjamur. Peneliti melakukan klasifikasi mutu I, II, III dan IV sesuai SNI (Standar Nasional Indonesia). Pada penelitian tersebut menggunakan mode warna RGB untuk melakukan ekstraksi fitur warna. Untuk pengolahan fitur bentuk menggunakan metode morfology dan menghitung nilai pixel citra. Dari 
implementasi pengujian dalam penelitian tersebut, terdapat output image segmentasi dari thresholding menjadi citra biner, morfology Dilasi, Erosi, dan Connected Component Labelling. Dalam ekstraksi bentuk terdapat spesifikasi nilai seperti jumlah biji, nilai pixel(max, min dan rata-rata) dan jumlah jenis biji. Untuk ekstraksi warna peneliti menilai spesifikasi dari nilai maximum, minimum dan ratarata nilai RGB dan dari kedua fitur tersebut nilai akan di input ke dalam tabel data test. Selanjutnya menentukan nilai $\mathrm{K}$ sebelum melakukan klasifikasi, terdapat pilihan nilai $\mathrm{K}$ yaitu K1, K2, K3, k4, K5, K6 dan K7 untuk melakukan klasifikasi. Hasil klasifikasi akan menampilkan nilai Pixel, warna RGB dan keterangan biji (utuh, berjamur, dan rusak) kemudian di simpan ke dalam data hasil. Pengujian akurasi sistem data diperoleh dari hasil pengujian sistem sesuai nilai $\mathrm{K}$ dan manual. Hasil akurasi penelitian ini sebesar 76,67\% dan presentase error sebesar 23,33\%. [21].

Penelitian dari K S H. Robert Singh yang berjudul A COMPARISON OF GRAY-LEVEL RUN LENGTH MATRIX AND GRAY-LEVEL COOCCURRENCE MATRIX TOWARDS CEREAL GRAIN CLASSIFICATION [17], hasil dari komparasi keakurasian klasifikasi tekstur menggunakan GLCM dan GLRLM sebagai berikut.

\begin{tabular}{|c|c|c|c|c|c|c|}
\hline \multirow{2}{*}{$\begin{array}{c}\text { GRAIN } \\
\text { TYPES }\end{array}$} & \multicolumn{2}{|c|}{ K-NN } & \multicolumn{2}{c|}{ SVM } & \multicolumn{2}{c|}{ BPNN } \\
\cline { 2 - 7 } & $\begin{array}{c}\text { GLCM } \\
\text { features }\end{array}$ & $\begin{array}{c}\text { 4 GLRLM } \\
\text { features }\end{array}$ & $\begin{array}{c}\text { 4 GLCM } \\
\text { features }\end{array}$ & $\begin{array}{c}\text { 4 GLRLM } \\
\text { features }\end{array}$ & $\begin{array}{c}\text { 4 GLCM } \\
\text { features }\end{array}$ & $\begin{array}{c}\text { 4 GLRLM } \\
\text { features }\end{array}$ \\
\hline TYPE1 & 87 & 99 & 94 & 99 & 96 & 99 \\
\hline TYPE2 & 96 & 100 & 100 & 100 & 100 & 100 \\
\hline TYPE3 & 92 & 100 & 96 & 99 & 96 & 99 \\
\hline TYPE4 & 81 & 100 & 99 & 100 & 99 & 100 \\
\hline
\end{tabular}

Gambar 1. Komparasi fitur tekstur

Dari Gambar 1 bahwa ekstraksi fitur menggunakan GLRLM dapat meningkatkan akurasi dalam ekstraksi fitur tekstur.

\subsection{Pengolahan Citra Digital}

Pengolahan citra digital adalah ilmu yang mempelajari tentang pengolahan citra. Kemudian dianalisis sehingga menghasilkan output berupa informasi yang bermanfaat.

\subsection{Metode tekstur Gray Level Run Length Matrix}

Gray Level Run Length Matrix(GLRLM) adalah metode analisis tekstur yang digunakan untuk membedakan tekstur halus dan kasar. Nilai tekstur dari GLRLM diperoleh dari nilai Short Run Emphasis(SRE), Long Run Emphasis(LRE), Grey Level Uniformity(GLU), dan Run Length Uniformity(RLU). Sebelum melakukan ciri tekstur. Kemudian menghitung fitur matrix menggunakan fitur GLRLM dibawah ini.

\footnotetext{
Diketahui

$\mathrm{i}=$ Tingkat keabuan

$\mathrm{j}=$ Nilai run
}

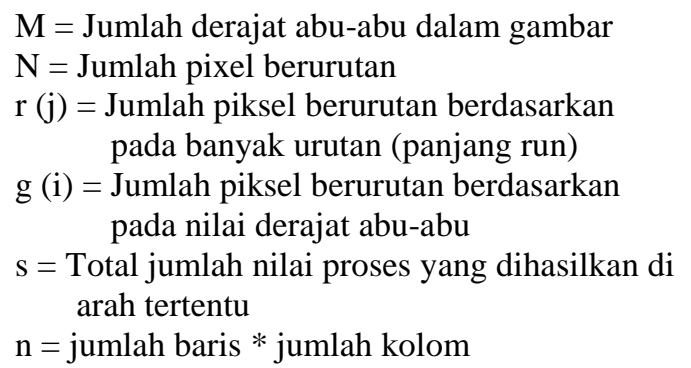

a. SRE

Untuk nilai SRE diharapkan bernilai besar pada tekstur yang halus. Untuk rumus SRE sebagai berikut

$$
S R E=\sum_{i=1}^{M} \sum_{j=1}^{N} \frac{p(i, j) / s}{j^{2}} \sum_{j=1}^{n} \frac{r(j) / s}{j^{2}}
$$

b. LRE

Nilai LRE diharapkan bernilai besar pada tekstur kasar. Untuk rumus LRE sebagai berikut

$$
L R E=\sum_{i=1}^{N} \sum_{j=1}^{M} \frac{J^{2} p(i, j)}{s}=\sum_{j=1}^{N} r(j) j^{2} / s
$$

c. GLU

Nilai GLU diharapkan bernilai kecil jika nilai derajat keabuan serupa seluruh citra pada gambar. Untuk rumus GLU sebagai berikut $G L U=\sum_{i=1}^{M}\left(\sum_{j=1}^{N} p(i, j)\right)^{2} / s \sum_{j=1}^{M} g(i)^{2} / s$

\section{d. RLU}

RLU fitur yang digunakan untuk mengukut persamaan panjangnya run di seluruh citra dan diharapkan bernilai kecil jika panjang run serupa pada citra. Untuk rumus RLU sebagai berikut. $R L U=\sum_{i=1}^{N}\left(\sum_{j=1}^{M} p(i, j)\right)^{2} / s \sum_{j=1}^{N} r(j)^{2} / s$

\subsection{Metode warna HSV}

HSV adalah mode warna dari Hue, Saturation, Value. HSV mempresentasikan warna dari merah, jingga, kuning, biru, ungu dan hijau. Hue adalah warna yang sering dijumpai oleh manusia contohnya seperti warna merah, Kuning, hijau dan sebagainya. Saturation adalah tingkat kemurnian suatu warna putih yang tercampur dengan nilai Hue. Value adalah banyaknya cahaya yang diterima oleh mata.

a. Mencari nilai Hue

$$
\begin{aligned}
R^{\prime} & =\frac{R}{255} \\
G^{\prime} & =\frac{G}{255} \\
B^{\prime} & =\frac{B}{255}
\end{aligned}
$$


$C \min =\min \left(R^{\prime}, G^{\prime}, B^{\prime}\right)$

$\Delta=C \max -C \min$

$$
H=\left\{\begin{array}{c}
0, \Delta=0 \\
60 x\left(\frac{G^{\prime}-B^{\prime}}{\Delta} \bmod 6\right), C \max =R^{\prime} \\
60 x\left(\frac{B^{\prime}-R^{\prime}}{\Delta}+2\right), C \max =G^{\prime} \\
60 x\left(\frac{R-G^{\prime}}{\Delta}+4\right), C \max =B^{\prime}
\end{array}\right.
$$

b. Mencari nilai Saturation

$S=\left\{\begin{array}{cc}0, C \max =0 \\ \frac{\Delta}{C \max }, C \max \neq 0\end{array}\right.$

c. Mencari nilai Value

$V=C \max$

\subsection{Metode K-Nearest Neighbors}

Algoritma K-Nearest Neighbors(K-NN) adalah sebuah metode yang melakukan klasifikasi dari sekumpulan data training yang kelasnya telah ditentukan sebelumnya. K-NN adalah metode yang termasuk supervised learning. Algoritma k- Nearest Neighbor menggunakan klasifikasi ketetanggaan (neighbor) sebagai nilai prediksi dari query instance yang baru. Algoritma ini sederhana, bekerja berdasarkan jarak terpendek dari query instance ke training sample untuk menentukan ketetanggaannya (Rizal, 2013).

Langkah - langkah perhitungan menggunakan K-NN sebagai berikut:

1. Menentukan parameter nilai $\mathrm{K}$

2. Menghitung distance atau jarak dengan data yang akan dievaluasi dengan semua data training.

3. Meranking jarak yang telah dihitung sebelumnya.

4. Menentukan jarak terdekat sampai urutan $\mathrm{k}$ yang ditentukan

5. Membandingkan banyaknya nilai dari data yang diambil

6. Memasukkan data yang telah dievaluasi dari nilai yang telah dibandingkan sebelumnya.

a. Perhitungan Jarak

Jarak Euclidean adalah jarak yang menggunakan rumus phytagoras. Untuk rumus Jarak Euclidean sebagai berikut.

$\mathbf{d}(\mathbf{x}, \mathbf{y})=\sqrt{\left(\mathbf{n} \sum \mathbf{i}=\mathbf{1}(\mathbf{x i}-\mathbf{y i})^{2}\right)}$

Diketahui:

- $\mathrm{Xi}=$ Sampel data

- $\quad \mathrm{Yi}=$ Data uji

- $\quad \mathrm{i}=$ Variabel data

- $\mathrm{d}(\mathrm{x}, \mathrm{y})=$ Jarak

- $\mathrm{n}=$ Dimensi data

\section{Metodologi}

Metode pengembangan menggunakan Waterfall Seperti pada Gambar 2 dibawah ini. Waterfall adalah metode pengembangan dimana proses pengembangan dilakukan secara berurutan seperti fase planning, design, implementation, dan testing.

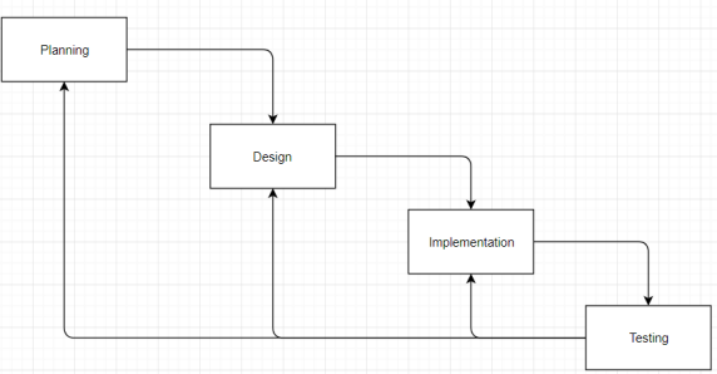

Gambar 2. Waterfall

\section{Perancangan}

\subsection{Deskripsi Sistem}

Pada Gambar 2 menjelaskan mengenai flowchart dari sistem. Penjelasan pada flowchart yaitu setelah membuka aplikasi, sistem akan menampilkan interface. Kemudian user dapat melakukan input citra gambar yang akan diolah. Selanjutnya citra diolah melalui proses Preprocessing Kemudian citra hasil preprosessing akan diproses ke ekstraksi fitur. Selanjutnya proses ekstraksi fitur warna dan tekstur. Untuk warna mengubah mode warna RGB menjadi HSV untuk mendapatkan nilai warna HSV. Untuk proses ekstrasi fitur tekstur merubah mode warna menjadi Grayscale kemudian analisis menggunakan GLRLM untuk analisis ekstraksi fitur tekstur. Hasil dari ekstraksi, untuk proses data training, maka akan masuk ke proses penyimpanan data ke dalam dataset untuk dijadikan nilai bobot K-NN. Untuk proses data uji, mengklasifikasi nilai output dari ekstraksi fitur menggunakan metode K-NN kemudian dihitung dengan nilai bobot dari dataset. Kemudian menghasilkan output apakah biji jagung layak atau tidak layak jual.

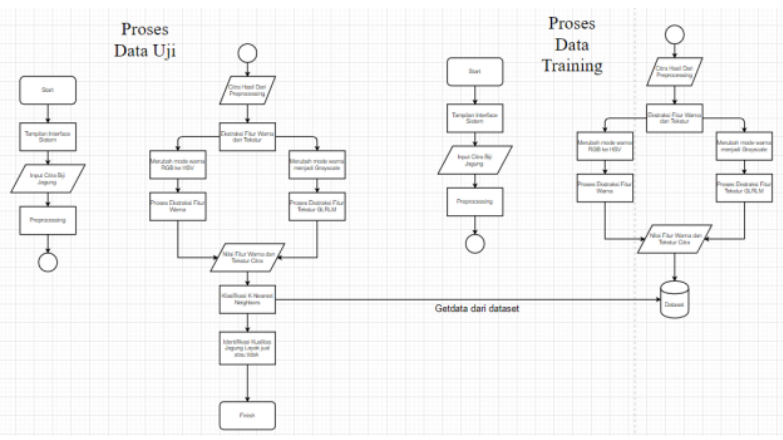

Gambar 3. Flowchart Sistem 


\subsection{Data}

Data berupa Biji Jagung Manis yang bewarna kuning yang di foto menggunakan kamera smartphone. Dari penilaian biji jagung manis sesuai kriteria dari hasil wawancara dengan narasumber di UD. Annur Sejahtera. Untuk biji jagung manis telah terkumpul sebanyak 160 biji yakni 30 biji jagung segar, 30 biji jagung patah segar, 30 biji jagung basi dan 30 biji jagung patah basi dan 40 biji data testing masing-masing 10 biji setiap citra.

\section{Implementasi}

\subsection{Implementasi Tampilan Sistem}

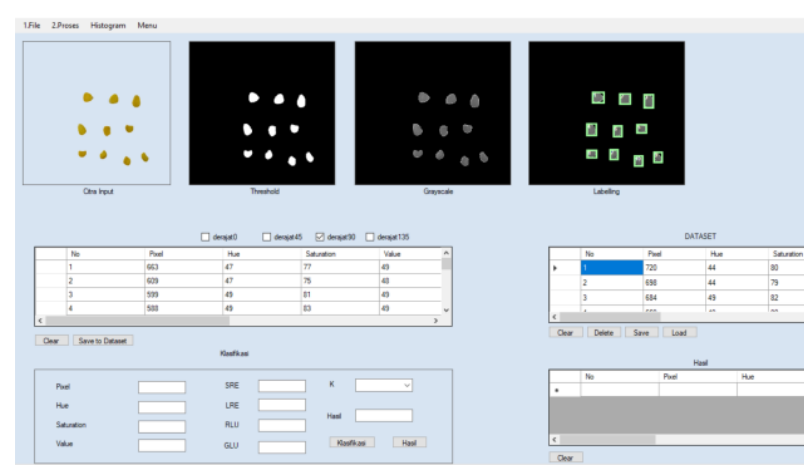

Gambar 4. Tampilan Sistem

Pada tampilan sistem seperti pada Gambar 3 terdapat 4 picturebox citra, 3 fitur pada menu panel terdiri dari Histogram, dan Proses. Menu Proses terdiri atas preprosesing Threshold, Grayscale, labeling, dan ekstraksi fitur Warna dan Tekstur. Menu panel histogram untuk menampilkan histogram pada citra grayscale seperti pada Gambar 4 .

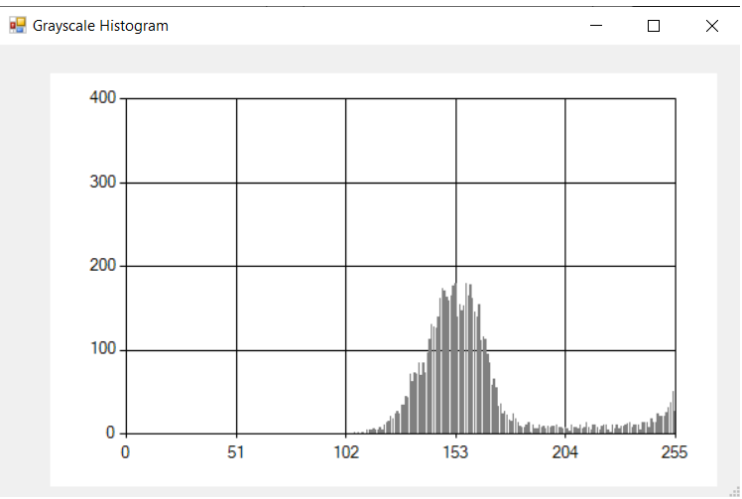

Gambar 5. Tampilan Histogram

\section{Pengujian dan Hasil}

Klasifikasi dilakukan dengan nilai K1, K3, K5, K7, K9 . Nilai akurasi diperoleh dari Jumlah klasifikasi benar (hasil perbandingan klasifikasi sistem dan prediksi manual) dibagi jumlah data testing keseluruhan yaitu terdapat 40 biji data testing, kemudian dikali $100 \%$. Untuk menghitung tingkat akurasi menggunakan rumus sebagai berikut.

Akurasi $=\frac{\text { Jumlah } \text { klasifikasi benar }}{\text { Jumlah uji keseluruhan }} \times 100 \%$

Dibawah ini setiap tabel masing-masing nilai $\mathrm{K}$ terdapat 10 biji jagung manis pada citra testing 1 , citra testing 2, citra testing 3, dan citra testing 4. Dikarenakan setiap derajat tekstur memiliki nilai yang berbeda sehingga diklasifikasi masing-masing derajat dan warna HSV menggunakan K-NN dengan nilai $\mathrm{K} 1, \mathrm{~K} 3, \mathrm{~K} 5, \mathrm{~K} 7$ dan $\mathrm{K} 9$

Tabel 1. Klasifikasi nilai K1

\begin{tabular}{|c|c|c|c|}
\hline Foto & Derajat & $\begin{array}{l}\text { Klasifikasi } \\
\text { Benar }\end{array}$ & $\begin{array}{l}\text { Klasifikas } \\
\text { i salah }\end{array}$ \\
\hline \multirow{4}{*}{$\because \because$} & 0 & 10 & 0 \\
\hline & 45 & 10 & 0 \\
\hline & 90 & 10 & 0 \\
\hline & 135 & 10 & 0 \\
\hline \multirow{4}{*}{$\because \because \therefore$} & 0 & 6 & 4 \\
\hline & 45 & 7 & 3 \\
\hline & 90 & 7 & 3 \\
\hline & 135 & 7 & 3 \\
\hline \multirow{4}{*}{$\because \because \vdots$} & 0 & 7 & 3 \\
\hline & 45 & 7 & 3 \\
\hline & 90 & 7 & 3 \\
\hline & 135 & 7 & 3 \\
\hline \multirow{4}{*}{$\therefore$} & 0 & 10 & 0 \\
\hline & 45 & 10 & 0 \\
\hline & 90 & 10 & 0 \\
\hline & 135 & 10 & 0 \\
\hline
\end{tabular}

Sehingga:

A. K1 dengan derajat tesktur 0

Akurasi $=\frac{33}{40} \times 100 \%$

Akurasi $=82,5 \%$

B. K1 dengan derajat tesktur 45

Akurasi $=\frac{34}{40} \times 100 \%$

Akurasi $=85 \%$

C. K1 dengan derajat tesktur 90

Akurasi $=\frac{34}{40} \times 100 \%$ 
Akurasi $=85 \%$

D. K1 dengan derajat tesktur 135

Akurasi $=\frac{34}{40} \times 100 \%$

Akurasi $=85 \%$

Tabel 2. Klasifikasi nilai K3

\begin{tabular}{|c|c|c|c|}
\hline Foto & Derajat & $\begin{array}{l}\text { Klasifikasi } \\
\text { Benar }\end{array}$ & $\begin{array}{l}\text { Klasifikas } \\
\text { i salah }\end{array}$ \\
\hline \multirow{4}{*}{$\begin{array}{ll}0 & 0 \\
0 & 0 \\
0 & 0\end{array}$} & 0 & 10 & 0 \\
\hline & 45 & 10 & 0 \\
\hline & 90 & 10 & 0 \\
\hline & 135 & 10 & 0 \\
\hline \multirow{4}{*}{$\because \because \because$} & 0 & 6 & 4 \\
\hline & 45 & 6 & 4 \\
\hline & 90 & 6 & 4 \\
\hline & 135 & 6 & 4 \\
\hline \multirow{4}{*}{$\because: \vdots$} & 0 & 6 & 4 \\
\hline & 45 & 6 & 4 \\
\hline & 90 & 6 & 4 \\
\hline & 135 & 6 & 4 \\
\hline \multirow{4}{*}{$\therefore$} & 0 & 10 & 0 \\
\hline & 45 & 10 & 0 \\
\hline & 90 & 10 & 0 \\
\hline & 135 & 10 & 0 \\
\hline
\end{tabular}

Sehingga:

A. K3 dengan derajat tesktur 0

Akurasi $=\frac{32}{40} \times 100 \%$

Akurasi $=80 \%$

B. $\mathrm{K} 3$ dengan derajat tesktur 45

Akurasi $=\frac{32}{40} \times 100 \%$

Akurasi $=80 \%$

C. K3 dengan derajat tesktur 90

Akurasi $=\frac{32}{40} \times 100 \%$

Akurasi $=80 \%$

D. K3 dengan derajat tesktur 135

Akurasi $=\frac{32}{40} \times 100 \%$

Akurasi $=80 \%$

Tabel 3. Klasifikasi nilai K5

\begin{tabular}{|l|l|l|l|}
\hline Foto & Derajat & $\begin{array}{l}\text { Klasifikasi } \\
\text { Benar }\end{array}$ & $\begin{array}{l}\text { Klasifik } \\
\text { asi salah }\end{array}$ \\
\hline \multirow{2}{*}{$*$} & 0 & 8 & 2 \\
\cline { 2 - 4 } & 45 & 8 & 2 \\
\cline { 2 - 4 } & 90 & 8 & 2 \\
\cline { 2 - 4 } & 135 & 8 & 2 \\
\hline & 0 & 5 & 5 \\
\hline & 45 & 5 & 5 \\
\hline
\end{tabular}

\begin{tabular}{|l|l|l|l|}
\hline Foto & Derajat & $\begin{array}{l}\text { Klasifikasi } \\
\text { Benar }\end{array}$ & $\begin{array}{l}\text { Klasifik } \\
\text { asi salah }\end{array}$ \\
\hline \multirow{2}{*}{$\therefore$} & 90 & 5 & 5 \\
\cline { 2 - 4 } & 135 & 5 & 5 \\
\hline \multirow{3}{*}{$\therefore$} & 0 & 6 & 4 \\
\cline { 2 - 4 } & 45 & 6 & 4 \\
\cline { 2 - 4 } & 90 & 6 & 4 \\
\cline { 2 - 4 } & 135 & 6 & 4 \\
\hline \multirow{2}{*}{$* \therefore$} & 0 & 10 & 0 \\
\cline { 2 - 4 } & 45 & 10 & 0 \\
\cline { 2 - 4 } & 90 & 10 & 0 \\
\cline { 2 - 4 } & 135 & 10 & 0 \\
\hline
\end{tabular}

Sehingga:

A. K5 dengan derajat tesktur 0 Akurasi $=\frac{29}{40} \times 100 \%$

Akurasi $=72,5 \%$

B. K5 dengan derajat tesktur 45

Akurasi $=\frac{29}{40} \times 100 \%$

Akurasi $=72,5 \%$

C. K5 dengan derajat tesktur 90

Akurasi $=\frac{29}{40} \times 100 \%$

Akurasi $=72,5 \%$

D. K5 dengan derajat tesktur 135

Akurasi $=\frac{72,5}{40} \times 100 \%$

Akurasi $=72,5 \%$

Tabel 4. Klasifikasi nilai K7

\begin{tabular}{|l|l|l|l|}
\hline Foto & Derajat & $\begin{array}{l}\text { Klasifikasi } \\
\text { Benar }\end{array}$ & $\begin{array}{l}\text { Klasifik } \\
\text { asi salah }\end{array}$ \\
\hline \multirow{2}{*}{$\therefore$} & 0 & 8 & 2 \\
\cline { 2 - 4 } & 45 & 8 & 2 \\
\cline { 2 - 4 } & 90 & 8 & 2 \\
\cline { 2 - 4 } & 135 & 8 & 2 \\
\hline \multirow{2}{*}{$\therefore$} & 0 & 6 & 4 \\
\cline { 2 - 4 } & 45 & 6 & 4 \\
\cline { 2 - 4 } & 90 & 6 & 4 \\
\cline { 2 - 4 } & 135 & 6 & 4 \\
\hline
\end{tabular}

$\mathrm{H}$ a $\mathrm{l}$ a $\mathrm{m}$ a $\mathrm{n} \mid \mathbf{4 1}$ 


\begin{tabular}{|l|l|l|l|}
\hline Foto & Derajat & $\begin{array}{l}\text { Klasifikasi } \\
\text { Benar }\end{array}$ & $\begin{array}{l}\text { Klasifik } \\
\text { asi salah }\end{array}$ \\
\hline \multirow{3}{*}{$\therefore$} & 0 & 5 & 5 \\
\cline { 2 - 4 } & 45 & 5 & 5 \\
\cline { 2 - 4 } & 90 & 5 & 5 \\
\cline { 2 - 4 } & 135 & 5 & 5 \\
\hline \multirow{3}{*}{$\therefore$} & 0 & 10 & 0 \\
\cline { 2 - 4 } & 45 & 10 & 0 \\
\cline { 2 - 4 } & 90 & 10 & 0 \\
\cline { 2 - 4 } & 135 & 10 & 0 \\
\hline
\end{tabular}

Sehingga:

A. K7 dengan derajat tesktur 0

$$
\begin{aligned}
& \text { Akurasi }=\frac{29}{40} \times 100 \% \\
& \text { Akurasi }=72,5 \%
\end{aligned}
$$

B. K7 dengan derajat tesktur 45

$$
\begin{aligned}
& \text { Akurasi }=\frac{29}{40} \times 100 \% \\
& \text { Akurasi }=72,5 \%
\end{aligned}
$$

C. K7 dengan derajat tesktur 90

$$
\begin{aligned}
\text { Akurasi } & =\frac{29}{40} \times 100 \% \\
\text { Akurasi } & =72,5 \%
\end{aligned}
$$

\begin{tabular}{|c|c|c|c|}
\hline Foto & Derajat & $\begin{array}{l}\text { Klasifikasi } \\
\text { Benar }\end{array}$ & $\begin{array}{l}\text { Klasifi } \\
\text { kasi } \\
\text { salah }\end{array}$ \\
\hline \multirow{4}{*}{$\begin{array}{lll}0 & 0 & 0 \\
0 & 0 & \bullet \\
\bullet & \bullet & 0\end{array}$} & 0 & 10 & 0 \\
\hline & 45 & 10 & 0 \\
\hline & 90 & 10 & 0 \\
\hline & 135 & 10 & 0 \\
\hline \multirow{4}{*}{$\because \because \bullet$} & 0 & 7 & 3 \\
\hline & 45 & 7 & 3 \\
\hline & 90 & 7 & 3 \\
\hline & 135 & 7 & 3 \\
\hline \multirow{4}{*}{$\begin{array}{lll}0 & 0 \\
0 & 0 & 0\end{array}$} & 0 & 5 & 5 \\
\hline & 45 & 5 & 5 \\
\hline & 90 & 5 & 5 \\
\hline & 135 & 5 & 5 \\
\hline \multirow{4}{*}{$\therefore$} & 0 & 10 & 0 \\
\hline & 45 & 10 & 0 \\
\hline & 90 & 10 & 0 \\
\hline & 135 & 10 & 0 \\
\hline
\end{tabular}

D. K7 dengan derajat tesktur 135

$$
\begin{aligned}
\text { Akurasi } & =\frac{29}{40} \times 100 \% \\
\text { Akurasi } & =72,5 \%
\end{aligned}
$$

Tabel 5. Klasifikasi nilai K9
Sehingga:

A. K9 dengan derajat tesktur 0

$$
\begin{aligned}
& \text { Akurasi }=\frac{32}{40} \times 100 \% \\
& \text { Akurasi }=80 \%
\end{aligned}
$$

B. K9 dengan derajat tesktur 45

$$
\begin{aligned}
& \text { Akurasi }=\frac{32}{40} \times 100 \% \\
& \text { Akurasi }=80 \%
\end{aligned}
$$

C. K9 dengan derajat tesktur 90

$$
\begin{aligned}
& \text { Akurasi }=\frac{32}{40} \times 100 \% \\
& \text { Akurasi }=80 \%
\end{aligned}
$$

D. K9 dengan derajat tesktur 135

Akurasi $=\frac{32}{40} \times 100 \%$

Akurasi $=80 \%$

Nilai $\mathrm{K}$ terbaik dan dari pengujian diatas terdapat pada $\mathrm{K} 1$, K3, dan $\mathrm{K} 9$ dengan Akurasi tertinggi sebesar $85 \%$.

\section{Kesimpulan dan Saran}

\subsection{Kesimpulan}

Penelitian yang telah dilakukan dapat ditarik kesimpulan sebagai berikut.Pada sistem ini metode ekstraksi fitur menggunakan Hue, Saturation, Value (HSV) sebagai fitur warna dan Gray Level Run Length Matrix (GLRLM) Ssebagai fitur tekstur, hasil dari GLRLM dihitung menggunakan metode fitur GLRLM SRE, LRE, RLU dan GLU. Hasil dari nilai ekstraksi fitur kemudian diklasifikasikan menggunakan metode K-NN. Hasil dari klasifkasi pada sistem Identifikasi Kualitas Biji Jagung Manis Layak Jual dari Warna dan Tesktur menggunakan metode $\mathrm{K}-\mathrm{NN}$, nilai $\mathrm{K}$ terbaik yaitu $\mathrm{K}=1, \mathrm{~K} 3$, dan $\mathrm{K}=9$ dan nilai akurasi tertinggi sebesar $85 \%$.

\subsection{Saran}

Dari penelitian ini masih memiliki kekurangan. Saran untuk penelitian selanjutnya adalah Menggunakan metode tekstur lainnya untuk mengetahui tingkat akurasi dari hasil ekstraksi fitur metode tersebut. Dapat ditambah dengan kelas objek jenis jagung lain. Pengambilan citra menggunakan kamera DSLR agar mendapatkan kualitas citra yang lebih baik.

\section{Daftar Pustaka:}

[1] Admin. (2014, 8 11). Jagung Pertiwi 2. Retrieved from benih pertiwi: http://benihpertiwi.co.id/jagung-pertiwi2/\#.Xh8S7sgzZPY

[2] Admin. (2016, 11 29). Asal Rasa Manis pada Jagung Manis. Retrieved from Benih Pertiwi: 
https://benihpertiwi.co.id/asal-rasa-manis-padajagung-manis/\#.Xh6M28gzZPa

[3] Agus Supriatna Somantri, M. \&. (2008). IDENTIFIKASI MUTU FISIK JAGUNG DENGAN MENGGUNAKAN PENGOLAHAN CITRA DIGITAL DAN JARINGAN SYARAF TIRUAN. Jurnal Standardisasi Vol. 10, No. 3 , $101-112$

[4] aguskhumaidi. (2019, September 5). Convert RGB To HSV for color tracking in Raspberry and openCV. Retrieved from Agus Khumaidi, S.ST.,M.T. Membahas Segala Hal Yang Berhubungan Dengan Otomasi : https://lecturer.ppns.ac.id/aguskhumaidi/2019/0 9/05/convert-rgb-to-hsv-for-color-tracking-inraspberry-and-opencv/

[5] Arni, U. D. (2018, Maret 27). Pengertian dan Penerapan Metode Learning Vector Quantization. Retrieved from Garuda Cyber Indonesia: https://garudacyber.co.id/artikel/530pengertian-dan-penerapan-metode-learningvector-quantization\#

[6] Cahyanti, S. R. (2010). ALGORITMA TRANSFORMASI RUANG WARNA. Depok.

[7] Djalu Ranadhi, W. I. (2006). IMPLEMENTASI LEARNING VECTOR QUANTIZATION (LVQ) UNTUK PENGENAL POLA SIDIK JARI PADA SISTEM INFORMASI NARAPIDANA LP WIROGUNAN. Media Informatika, Vol. 4, No. 1., 51-65.

[8] Dzulfikar, M. A. (2014). Analisis Distribusi Intensitas RGB Citra Digital untuk Klasifikasi Kualitas Biji Jagung menggunakan Jaringan Syaraf Tiruan. JURNAL FISIKA DAN APLIKASINYA VOLUME 10, NOMOR 3., 127132.

[9] Endina Putri Purwandari, R. U. (2018). Identifikasi Jenis Bambu Berdasarkan Tekstur Daun dengan Metode Gray Level Co-Occurrence Matrix dan Gray Level Run Length Matrix. Jurnal Teknologi dan Sistem Komputer, 6(4)., 146-151.

[10]Fikry Destian, F. A. (2015). Algoritme Thresholding Paralel Dengan Skema Partisi Rowwise. Retrieved from https://cs.ipb.ac.id/ auriza/parallel/projek/1.8/th reshold.html

[11] Ida Ayu A. Angreni. Sakti Adji Adisasmita, M. I. (September 2018). PENGARUH NILAI K PADA METODE K-NEAREST NEIGHBOR (KNN) TERHADAP TINGKAT AKURASI IDENTIFIKASI KERUSAKAN JALAN. Rekayasa Sipil, Vol. 7 No. 2, 63-70.

[12] Imam Santoso, Y. C. (2007). KINERJA PENGENALAN CITRA TEKSTUR MENGGUNAKAN ANALISIS TEKSTUR METODE RUN LENGTH. Seminar Nasional Aplikasi Teknologi Informasi 2007 (SNATI 2007) , F-19 - F-25.
[13] pamungkas, a. (2016, April 21). k-Nearest Neighbor (k-NN) Menggunakan Matlab. Retrieved from Pemrograman Matlab: https://pemrogramanmatlab.com/2016/04/21/knearest-neighbor-k-nn-menggunakan-matlab/

[14] pamungkas, a. (2017, Juli 26). Histogram Citra. Retrieved from Pemrograman Matlab: https://pemrogramanmatlab.com/2017/07/26/his togram-citra/

[15] Pomade, D. (2016). Learning Vector Quantization ( $L V Q)$. Retrieved from Slideplayer: https://slideplayer.info/slide/3080312/

[16] SABIQ ADZHANI HAMMAM, T. W. (2017). COTTON TEXTURE SEGMENTATION BASED ON IMAGE TEXTURE ANALYSIS USING GRAY LEVEL RUN LENGTH AND EUCLIDEAN DISTANCE. Journal of Theoretical and Applied Information Technology, Vol.95. No 24, 6915-6923.

[17] Singh, K. S. (2016). A COMPARISON OF GRAY-LEVEL RUN LENGTH MATRIX DAN GRAY LEVEL CO-OCCURRENCE MATRIX TOWARD CEREAL GRAIN CLASSIFICATION. International Journal of Computer Engineering \& Technology (IJCET) Volume 7, Issue 6, Article ID: IJCET_07_06_002,9-17.

[18] SITI MUTROFIN, S. ,. (2015). Ekstraksi Fitur Warna Menggunakan Hue Saturation Value Untuk Klasifikasi Tumbuhan Berdasarkan Citra Daun. Jombang: UNIVERSITAS PESANTREN TINGGI DARUL ULUM.

[19] Sulityawati, D. H. (2018). Analisa Citra Parasit Malaria Dalam Ruang Warna Hue Saturation Value (HSV). Jurnal Hasil Penelitian LPPM Untag Surabaya, Vol. 03, No. 01, 63-66.

[20] Sunarti, D. d. (2017, December 22). Penanganan Panen dan Pasca Panen Jagung untuk Tingkat Mutu Jagung. Retrieved from Balai Pengkajian Teknologi Sulawesi Utara : http://sulut.litbang.pertanian.go.id/index.php/10 6-infoteknologi4/810-penanganan-panen-danpasca-panen-jagung-untuk-tingkat-mutu-jagung

[21] Ulla Delfana Rosiani, M. M. (2019). Klasifikasi Kualitasi Biji Jagung Berdasarkan Warna dan Bentuk Menggunakan Metode K-Nearest Neighbor. Teknik Informatika, Politeknik Negeri Malang, 1-5. 
Volume 7, Edisi 1, November 2020

$44 \mid \mathrm{H}$ a 1 a $\mathrm{m}$ a $n$ 